\title{
Feasibility study on solar district heating in China
}

\author{
Huang, Junpeng; Fan, Jianhua; Furbo, Simon
}

\section{Published in:}

Renewable and Sustainable Energy Reviews

Link to article, DOI:

10.1016/j.rser.2019.03.014

Publication date:

2019

Document Version

Peer reviewed version

Link back to DTU Orbit

Citation (APA):

Huang, J., Fan, J., \& Furbo, S. (2019). Feasibility study on solar district heating in China. Renewable and Sustainable Energy Reviews, 108, 53-64. https://doi.org/10.1016/j.rser.2019.03.014

\section{General rights}

Copyright and moral rights for the publications made accessible in the public portal are retained by the authors and/or other copyright owners and it is a condition of accessing publications that users recognise and abide by the legal requirements associated with these rights.

- Users may download and print one copy of any publication from the public portal for the purpose of private study or research.

- You may not further distribute the material or use it for any profit-making activity or commercial gain

- You may freely distribute the URL identifying the publication in the public portal

If you believe that this document breaches copyright please contact us providing details, and we will remove access to the work immediately and investigate your claim 


\title{
Feasibility Study On Solar District Heating In China \\ Junpeng Huang, Jianhua Fan*, Simon Furbo \\ Department of Civil Engineering, Technical University of Denmark, Copenhagen (Denmark)
}

\begin{abstract}
Solar thermal has contributed little for space heating in China. In 2014, although China shared $75.8 \%$ of the total solar collector installations in the world, only less than $0.3 \%$ of the solar collectors were used for space heating. To promote solar district heating (SDH) in China, based on Danish experiences and Chinese clean heating transformation practices, a PEST (policy, economics, social, and technology) analysis and a SWOT (strengths, weaknesses, opportunities, and threats) analysis on SDH development in China were conducted. An extensive survey and on-site investigation were carried out to identify the applicability of SDH in rural areas. SDH development strategies, roadmap, and decision-making process for a SDH project are summarized. SDH has a broad application prospect in China with abundant solar resources and favorable policies. The solar heated floor area can achieve 756 million $\mathrm{m}^{2}$ with an assumption of $3 \%$ coverage of the total heat demand of buildings. Particular areas with low population density, scarce resources, and strict environmental requirements, e.g., Tibet, should be given a high priority for SDH. Rural villages and small towns with a better infrastructure, e.g., district heating networks, are the best target market for SDH in the next five years. With the development of seasonal heat storage technologies and the accumulation of practical experience, SDH can be expanded to industrial parks, large residential communities in sparsely populated northwest China. Integration of solar heat with existing heating networks in big cities with central heating will be challenging in the long run.
\end{abstract}

\section{Highlights}

- Solar district heating has a broad application prospect in China. The solar heated area can achieve 756 million $\mathrm{m}^{2}$ with an assumption of $3 \%$ coverage of the total heat demand of buildings.

- High-performance flat plate collectors will significantly increase the reliability and reduce the operation \& maintenance cost of solar district heating systems.

- A solar assisted ground source heat pump system is a reliable solution as a form of solar district heating.

\footnotetext{
* Corresponding author. ISES member Tel: +45-42251889 Fax: +45-45883282

Email addresse: jif@byg.dtu.dk (Jianhua Fan)
} 
- Particular areas with low population density, scarce resources, and strict environmental requirements, e.g., Tibet, should be given high priority for solar district heating.

- Land availability is a significant obstacle to the development of large-scale solar district heating.

Keywords: Solar district heating; Clean heating; Feasibility study; Roadmap

Word Count: 7594

\begin{tabular}{|ll|}
\hline Abbreviations \\
SDH & solar district heating \\
ASHP & air source heat pump \\
GSHP & ground source heat pump \\
COP & coefficient of performance \\
SF & solar fraction \\
CHP & combined heat and power \\
PEST & politics, economics, social, and technology \\
SWOT & strengths, weaknesses, opportunities, and threats \\
LCOH & levelized cost of heat \\
FPC & flat plate solar collector \\
ETC & evacuated tube solar collector \\
\hline
\end{tabular}

\begin{tabular}{|cl}
\hline Symbols & \\
$I_{0}$ & the initial investment, CNY \\
$S_{0}$ & subsidies and incentives, CNY \\
$C_{t}$ & operation and maintenance costs, CNY \\
$E_{t}$ & the total energy demand, kWh \\
$T R$ & the tax rate, \% \\
$D E P_{t}$ & the asset depreciation (year t), CNY \\
$R V$ & the residual value of system, CNY \\
$r$ & the discount rate, \% \\
$T$ & the period of analysis, year \\
$p_{\text {land }}$ & the annual land rent, CNY/year
\end{tabular}

\subsection{Introduction}

Solar district heating (SDH) plants are district heating systems with solar thermal as a vital 
energy source. SDH has a long history in the Scandinavian countries. Sweden was the earliest country to develop SDH technologies. In 1979 and 1980, two large-scale SDH systems were established[1]. Based on Sweden's experience, Denmark, Austria and other European countries developed their solar heating technologies rapidly. The first SDH system using flat plate collectors in Denmark was built in 1988 and was connected to an existing district heating network[2]. By the end of 2017, 296 large-scale SDH systems (capacity > $350 \mathrm{~kW}$ th; collector area $>500 \mathrm{~m}^{2}$ ) were in operation. The total installed collector area of SDH systems reached $1,741,344 \mathrm{~m}^{2}[3]$.

Denmark leads the development and application of SDH technologies with the largest installed solar collector area and the largest number of SDH projects in operation in the world. Solar thermal covered only $0.15 \%$ of the total heat supply in Denmark in 2010[4], but the contribution increased to $2 \%$ in 2017 and is expected to achieve 15\% by 2025[5]. By the end of 2017, more than 105 plants were operating in Denmark, with a total solar collector area of $1,327,451 \mathrm{~m}^{2}[6]$. Denmark plans to phase out all fossil fuels before 2050 , and to produce all heat and electricity by renewable energy before 2035 , which means solar thermal utilizations will play an important role in the energy roadmap of the country.

However, solar thermal has contributed little for space heating in China, although China shares $75.8 \%$ of the total installation of solar collectors in the world[7] and faces serious air pollution problems caused by coal burning. Less than $0.3 \%$ of the total solar collector installations were used for space heating in 2014 . Only about $150,000 \mathrm{~m}^{2}$ solar collectors were used for space heating in China in 2014, much less than that in Europe. Most solar collectors were used in rural areas as single unit water heaters to produce domestic hot water (thermal siphon system) in China.

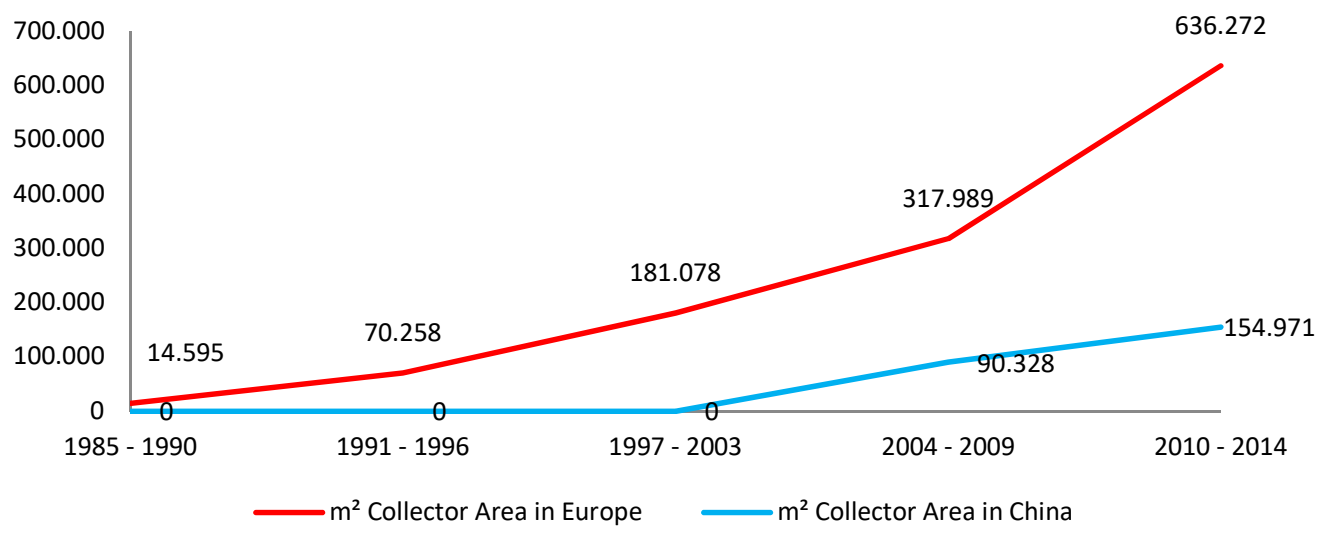

Figure 1 Installed collector area for space heating in China and European countries from 1985 - $2014[7]$

China is facing tremendous pressure to reduce emissions caused by coal burning for space 
heating. In northern China, the primary fuel for space heating in winter was coal. Coal-fired heating accounted for $81 \%$ of the total heated area before 2016 [8]. The annual consumption of coal for space heating was 400 million tons of standard coal equivalent, of which about 200 million tons of standard coal equivalent were bulk coal, including coal for low-efficiency small boilers. Bulk coal was mainly used in rural areas. High-intensity use of coal caused severe air pollution. It was reported that over 366,000 people died early from diseases caused by air pollution due to coal burning in China in 2013[9]. It is imperative to use clean energy to substitute bulk coal for space heating. As an infinite clean energy source, solar thermal should contribute more substantially in the energy transformation.

\subsection{Background}

\subsection{Household solar heating}

There were some pilot household solar heating projects in Beijing rural areas in early 2010. The building areas were between $90 \sim 210 \mathrm{~m}^{2}$. Solar collector areas and volumes of water tanks in different houses ranged $14 \sim 60 \mathrm{~m}^{2}$ and $0.3 \sim 1.5 \mathrm{~m}^{3}$ respectively. A farmhouse with flat plate solar collectors on the roof and the schematic of the solar heating systems in the houses are shown in Figure 2.

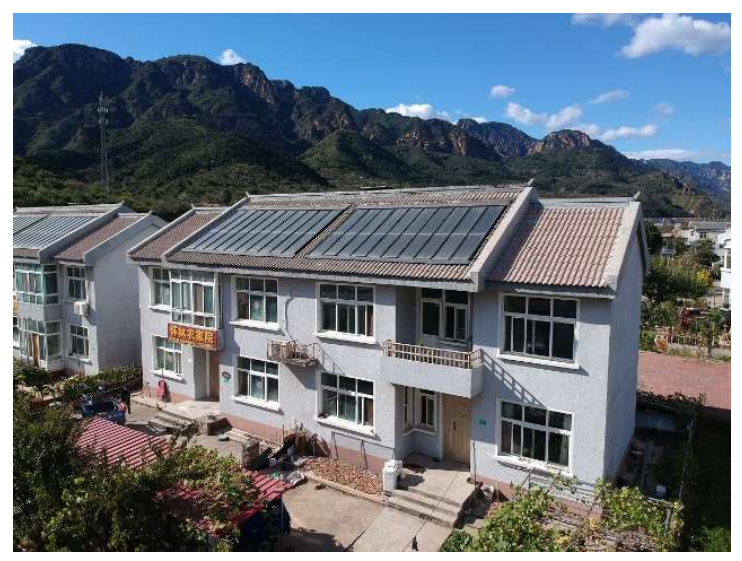

A farmhouse with flat plate solar collectors on the roof in Jiangjunguan Village

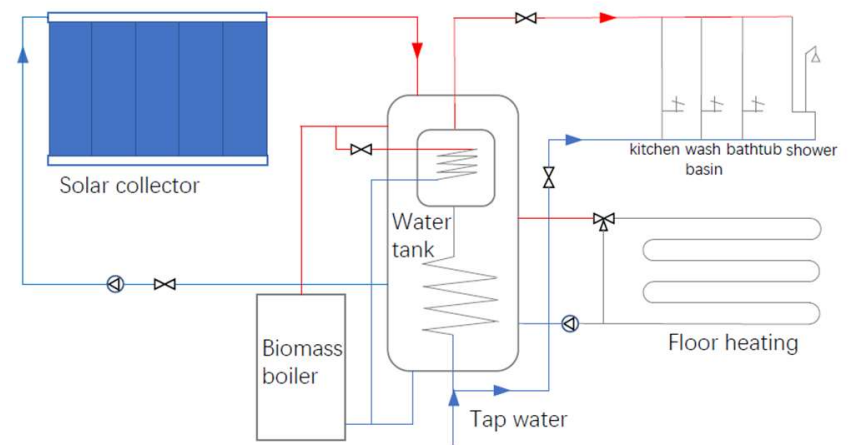

The System schematic of the household solar heating systems

Figure 2 Typical household solar heating project in Beijing, China

A post-use survey[10] was conducted for these household solar heating projects in 2016 . The on-site survey and test revealed that solar heating systems could save $60 \%$ of the coal burning annually (including domestic hot water). The contribution rate to space heating is $30.7 \%$, but the systems did not run steadily. The operation and maintenance were mainly conducted by the users. Because of a lack of professional knowledge, many users (farmers) experienced the helplessness when the systems failed. 
Due to the limited installation areas for collectors on the roof, the system could not provide enough heat in winter to keep a comfortable room temperature. The measured average room temperature was $12{ }^{\circ} \mathrm{C}$ without an auxiliary heat source[11]. However, the system provided too much domestic hot water in summer, and the redundant collectors caused overheating of the systems, which shortened the lifespan of the systems and frequently caused bursting of evacuated tube collectors.

The unsuccessful experience of the household solar heating projects caused decision-makers to lose confidence in solar heating, making solar thermal less preferred in the clean heating campaigns.

\subsection{Advantages of SDH}

A SDH system with long-term / seasonal heat storage can resolve most problems in household solar heating projects. In addition to the advantages of reduced operating costs, reduced greenhouse gasses, potentially pollution free, 100\% renewable and local, SDH has the following advantages compared with household solar heating.

\section{1) High efficiency}

A hybrid energy system in a solar heating plant has a higher efficiency than conventional heating equipment. From the survey of existing household space heating systems in Beijing rural areas, the Seasonal Coefficient of Performance (COP) of different heating solutions are listed in Table 1. The Seasonal COP is the total heating output of a heat device / system during its normal annual usage period for heating divided by the total electric energy input during the same period in $\mathrm{KWh}[12],[13]$. The survey showed that the combinations of solar thermal with conventional heat sources had a much higher Seasonal COP than the individual heating solutions. In a Canada case, the Seasonal COP even reached more than 30[14].

Table 1 An efficiency comparison for existing household space heating systems in Beijing rural areas

\begin{tabular}{lll}
\hline & Seasonal COP & Electricity consumption \\
\hline ASHP+floor heating & $\geq 2.8$ & $37 \sim 55 \mathrm{kWh} / \mathrm{m}^{2}$ \\
\hline ASHP+ Radiator & $\geq 2.3$ & $37^{\sim 55} \mathrm{kWh} / \mathrm{m}^{2}$ \\
\hline Regenerative Electric heating & $<1$ & $125 \sim 180 \mathrm{kWh} / \mathrm{m}^{2}$ \\
\hline Electric Boiler+Radiator & $<1$ & $>150 \mathrm{kWh} / \mathrm{m}^{2}$ \\
\hline Electric floor heating & $<1$ & $100 \sim 150 \mathrm{kWh} / \mathrm{m}^{2}$ \\
\hline Solar+ASHP & $>3.5$ & $33^{\sim} 40 \mathrm{kWh} / \mathrm{m}^{2}$ \\
\hline SDH+BTES* & $>30$ & $\sim 1.85 \mathrm{kWh} / \mathrm{m}^{2}$ \\
\hline
\end{tabular}

*The data comes from Drake Landing Solar Community in the Town of Okotoks, Alberta, 
Canada[14].

\section{2) High flexibility}

Flexibility is the ability of the system to shift the use of a certain amount of energy in time and to utilize different energy sources[15]. For a higher solar fraction (SF), SDH systems need short-term or long-term heat storage facilities, which makes it possible for a combination of various heat sources, including all types of renewable heat (geothermal and biomass), waste heat (from waste incineration and excess heat from industries) and heat generated by electric driven heat pumps and by cogeneration plants, etc. .

Figure 3 shows a typical hybrid energy SDH plant in Marstal, Denmark. The system supplies heat to 1,600 consumers. $50-55 \%$ of heat production comes from solar collectors, $40 \%$ from a wood pellet boiler, 2-3\% from a heat pump and the rest from a bio-oil boiler. The plant produces hot water directly to the district heating network, and surplus heat is stored in the water storage in summer. The heat pump runs when the electricity prices are low enough to heat the return temperature to $75^{\circ} \mathrm{C}$ by cooling down the storage. The wood chip boiler and the organic Rankine cycle unit can run at a full load, so that the plant sells electricity to the grid when the electricity prices are high enough in winter. This system shows that cheap electrical energy can replace scarce biomass in a large-scale SDH plant with a large storage capacity[16].

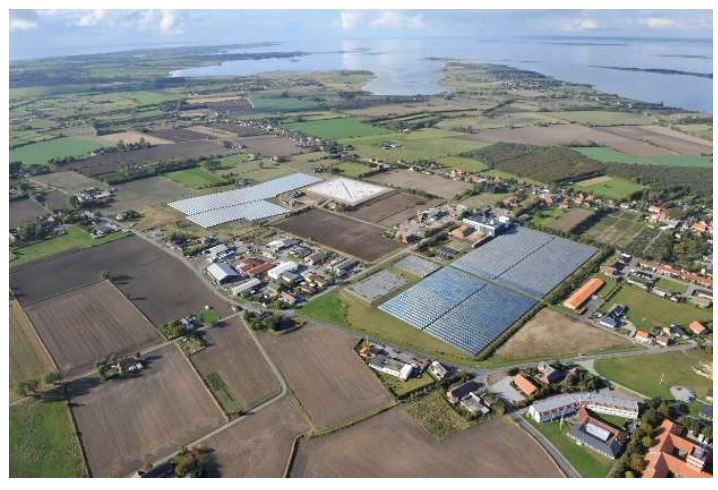

An aerial view of the SUNSTORE heating plant in Marstal, Denmark

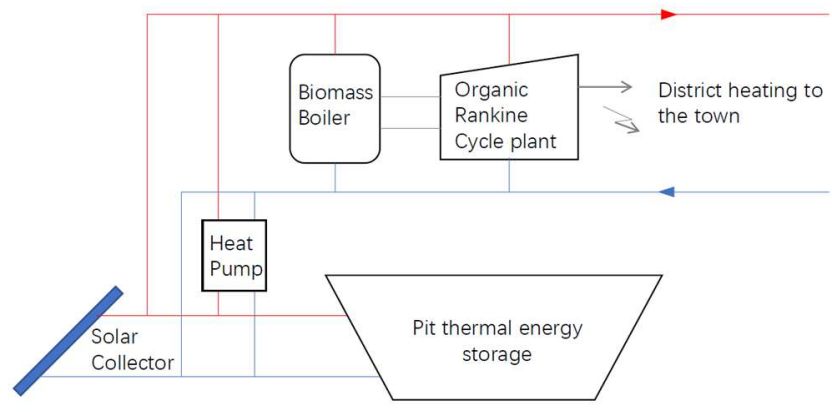

The System schematic of the SUNSTORE heating plant in Marstal, Denmark

Figure 3 A typical solar district heating project in Marstal, Denmark

\section{3) Management convenience}

District heating schemes implement a community-based management approach that is highly compatible with the current New Rural Construction concept promoted by the Chinese government. District heating schemes in a village provide space heating services in a unified manner and charges fees uniformly. District cooling could also be integrated into the scheme 
providing lower cost cooling to commercial users. It is more convenient for users to operate and to maintain the plant. District heating schemes also reduce the risk of gas leaks and the risk of fire explosion.

\subsection{Danish experiences}

As a mature clean heating technology, SDH can effectively reduce the use of coal for the Chinese space heating industry. It is essential to learn the successful experience of the rapid development of SDH in Denmark for Chinese practitioners[17]. Generally, the success factors for SDH in Denmark include both social factors and technical factors.

Social factors mean politics, market, and social awareness of environmental protection and renewable energy utilization.

1) Taxes on natural gas, the ban on new biomass and natural gas-fired combined heat and power plants. There is no tax on solar thermal[18].

2) The government sets an ambitious target for clean energy transition and takes effective supportive policies, such as incentives for renewable energy and high tax for fossil fuels.

3) A tradition for low-temperature district heating[19] and available district heating networks in the countryside with lower population density.

4) A low price of land makes ground-mounted solar collector fields low cost possible.

5) Competitive heat price, the average heat price for SDH plants is about $0.23 \mathrm{CNY} / \mathrm{KWh}$. Compared with 0.69 CNY / KWh including taxes for conventional district heating in Denmark, the price is much lower.

6) Maintain a high share of wind energy and small combined heat and power (CHP) plants in small towns.

7) Benefits from the liberal electricity market, some SDH plants with CHP can sell electricity to the grid when the price of electricity is high, which makes additional profits for the SDH plants.

The technical factors mean specific technologies, or design concepts for SDH, which are simple, well proven and reliable.

1) SDH has shown reliability over the last $25 \sim 30$ years.

2) A SDH plant is often installed in smaller towns with more than 5,000 inhabitants. The distance from the collector field to the district heating network is typically within 200 $\mathrm{m}[20]$.

3) The lower service temperature for district heating: $70-80^{\circ} \mathrm{C}$ for supply, $35-45^{\circ} \mathrm{C}$ for return[19], which makes the integration of the solar collector field with heating network possible with a higher efficiency. 
4) More than $90 \%$ of the SDH plants use large flat plate collectors[21], high efficient flat plate collectors with long lifetime ensure the high reliability and efficiency of the whole system. The large modules of flat plate collectors further reduce the installation cost.

5) The use of seasonal heat storage pits allows shifting the delivery of solar heat from periods of higher production and lower demand in summer to the heating season in winter.

6) Reasonable solar fraction, 16 - $24 \%$ are the most popular so far[20], some of the SDH plants reach 50 - 70\% with seasonal heat storages[19].

7) The integration of hybrid energy sources improves the reliability of the whole system.

Although it is impossible to competely copy the experience of applying SDH in Denmark, China has a unique advantage for development of SDH in terms of rich solar radiation, lower labour costs, and strong industrial base. In order to promote the clean transformation of the Chinese space heating industry and to promote the development of the solar thermal industry, it is necessary to conduct a feasibility study on the applicability of SDH in China to identify the opportunities and challenges.

\subsection{Method}

A PEST analysis and A SWOT analysis will be carried out in the study. PEST analysis is a widely used model that applies environmental scanning to analyze the four factors of politics, economics, social, and technology in the overall environment, firstly proposed by the Harvard professor Francis Aguilar[22]. This strategic tool can help decision-makers effectively understand the growth or decline, the potential, and direction of the market. In the feasibility study, these four factors refer to policy environment, economic feasibility, technical feasibility, and market feasibility.

\begin{tabular}{|c|c|c|}
\hline 1. PEST analysis & 2. SWOT analysis & 3. Development Strategies \\
\hline $\begin{array}{c}\text { Policy } \\
\text { environment }\end{array}$ & Strengths & \\
\hline $\begin{array}{c}\text { Economic } \\
\text { feasibility }\end{array}$ & Weaknesses & \begin{tabular}{|c|} 
Decision-making \\
process
\end{tabular} \\
\hline $\begin{array}{c}\text { Technical } \\
\text { feasibility }\end{array}$ \\
\hline $\begin{array}{c}\text { Market } \\
\text { feasibility }\end{array}$
\end{tabular}


Figure 4 The concept of the feasibility study

To propose SDH development strategies, a SWOT analysis will be conducted. SWOT analysis is a strategic planning technique used to help an organization identify strengths, weaknesses, opportunities, and threats related to business competition or project planning[23]. Strengths and weakness are frequently internally-related, while opportunities and threats commonly focus on the external environment. The concept of the investigations is shown in Figure 4.

An extensive survey and on-site investigation on typical household solar heating projects in Beijing rural were carried out to identify the applicability of SDH in rural areas.

\subsection{Policy environment}

\subsection{The Clean Heating Plan}

To deal with the severe air pollution in the Jing-Jin-Ji Region, the Chinese government published an action plan in 2013[24]. The plan called for a decrease in the concentration of inhalable particulates in cities across the country by more than 10\% compared with 2012.

In 2017, the National Energy Administration of China published the Clean Heating Plan in North China in Winter (2017-2021). The plan set a goal for reducing the use of coal by increasing the use of renewable energy, heat pumps and industrial waste heat in the next five years. The proposed energy structure for space heating in 2021 is shown in Table 2 for a comparison with that in 2016 . $0.18 \%$ of the building area will be heated by solar thermal in 2021 according to the plan. The target on solar heating is a small step for the space heating industry of China, but for the solar thermal industry, this is a big step. Because the plan opened up the policy window for solar thermal for space heating, it created conditions for the widespread use of SDH.

Table 2 Energy structure of heating in China in 2016 and 2021[8]

\begin{tabular}{|c|c|c|c|c|}
\hline & \multicolumn{2}{|c|}{2016} & \multicolumn{2}{|c|}{2021} \\
\hline & Heated area & Percentage & Heated area & Percentage \\
\hline & 100 million $\mathrm{m}^{2}$ & - & 100 million $\mathrm{m}^{2}$ & - \\
\hline Gas & 22 & $10.7 \%$ & 40 & $14.1 \%$ \\
\hline Electricity & 4 & $1.94 \%$ & 15 & $5.28 \%$ \\
\hline Electric boiler & 1 & $0.49 \%$ & 3 & $1.06 \%$ \\
\hline Decentralized electric heating & 2.8 & $1.36 \%$ & 7 & $2.46 \%$ \\
\hline Air source heat pumps & 0.2 & $0.10 \%$ & 5 & $1.76 \%$ \\
\hline Clean coal $^{\mathrm{a}}$ & 35 & $17.0 \%$ & 110 & $38.7 \%$ \\
\hline Renewable energy & 8 & $3.88 \%$ & 34 & $11.8 \%$ \\
\hline Geothermal $^{b}$ & 5 & $2.43 \%$ & 10 & $3.52 \%$ \\
\hline Biomass energyc & 2 & $0.97 \%$ & 21 & $7.39 \%$ \\
\hline Solar thermal & 0 & - & 0.5 & $0.18 \%$ \\
\hline
\end{tabular}




\begin{tabular}{|c|c|c|c|c|}
\hline Industrial waste heat ${ }^{d}$ & 1 & $0.49 \%$ & 2 & $0.70 \%$ \\
\hline $\begin{array}{l}\text { Clean heating rate }{ }^{\mathrm{e}} \text { (Summary of } \\
\text { the above various heat sources) }\end{array}$ & 69 & $33.5 \%$ & 199 & $70 \%$ \\
\hline Bulk coalf $^{f}$ & 137 & $66.5 \%$ & 85 & $30 \%$ \\
\hline Total & 206 & $100 \%$ & 284 & $100 \%$ \\
\hline
\end{tabular}

Note:

a, Clean coal means clean coal-fired central heating, which is a way to deliver heat for the users through the heating pipe network after implementing ultra-low emission transformation of coal-fired cogeneration plants and coal-fired boilers.

b, Geothermal heating includes medium-deep geothermal heating and shallow geothermal heating (ground source, water source heat pump in electric heating).

c, Biomass energy includes agroforestry biomass cogeneration, urban domestic waste cogeneration, biomass briquettes, bio-natural gas, and other biomass gasification heat sources.

d, Industrial waste heat excluding heat recovery from power plants.

e, clean heating rate refers to the ratio of the building area that is heated by gas, electricity, renewable energy and clean coal technologies to the total heated floor area.

$\mathrm{f}$, bulk coal refers to the coal used in small boilers and small kilns, as well as the coal used in residential and service industries. China consumes 200 million tons of bulk coal every year for space heating. Bulk coal is currently the most crucial heating energy source in rural North China and the primary source of air pollution in winter.

To implement the plan, the Chinese government initiated a clean heating movement with systematic incentive policies, as shown in Figure 5, the incentive policy covers three parts: Infrastructure construction, equipment purchase, and operating. The high subsidies from initial investment to operating costs have significantly lowered the threshold for implementing SDH.

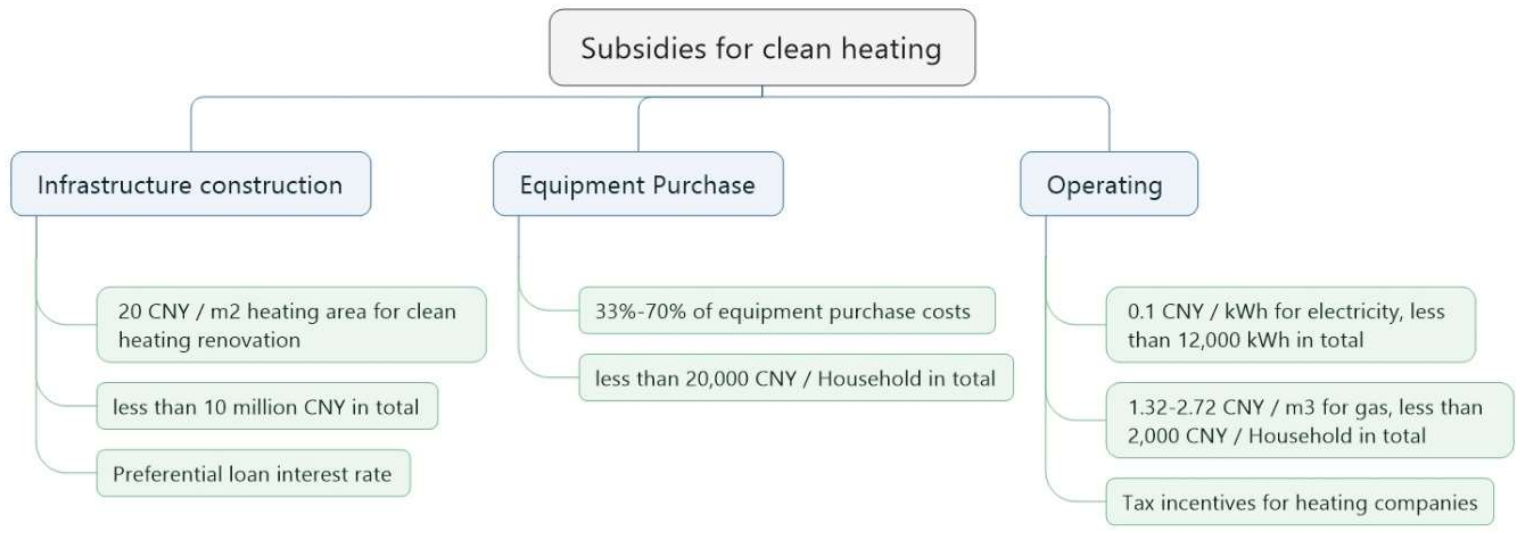

Figure 5 Incentive policy structure for clean heating in China

To achieve immediate results, some local authorities directly implemented the clean heating 
strategy as Coal to Electricity Transformation and Coal to Gas Transformation, without paying enough attention to renewable energy sources such as solar and biomass energy.

Take Beijing as an example. According to the Investigation Report on Coal to Clean Energy for Beijing Residents by Beijing Municipal Bureau of Statistics published in December 2017[25], shown in Figure 6, among the surveyed 536 households, 275 households used air source heat pumps (ASHP) or ground source heat pumps (GSHP), accounting for $51.3 \%$ of the total number of households. 120 households used gas boilers, accounting for $22.4 \%$. Regenerative electric heaters accounted for $18.5 \%$, and the remaining $7.8 \%$ for electric boilers and other methods[25]. There was no solar heat.

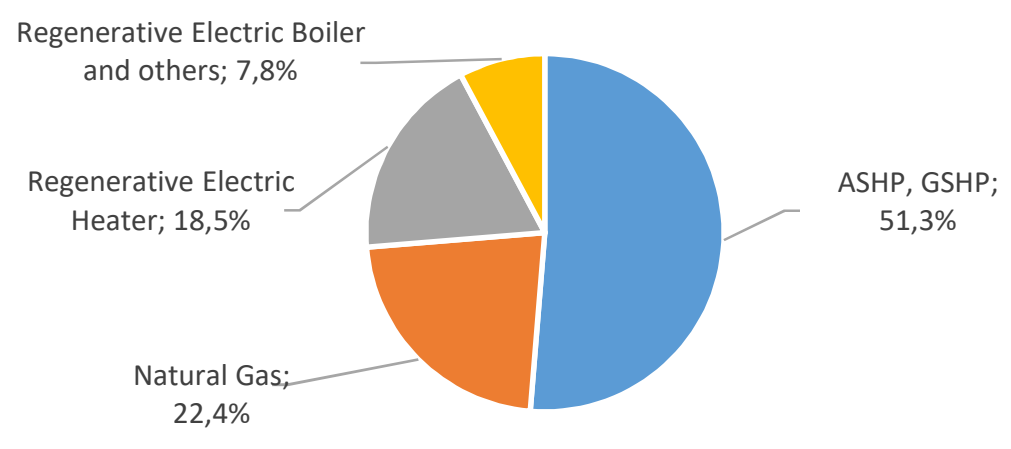

Figure 6 Heating methods of households interviewed for clean heating in Beijing[25]

Coal to Electricity and Coal to Gas policies may bring some immediate results. However, the implementation of these two policies relied on subsidies and an adequate natural gas supply. It is challenging to be implemented in some economically underdeveloped regions.

\subsection{Coal to Electricity Transformation}

Due to the slowdown in economic growth, China's electricity production was in surplus. In 2017, the average utilization hours of thermal power equipment was 3,772 hours, and the supply and demand of electricity showed an oversupply situation[26]. As an essential way to prevent and control atmospheric pollution to improve the quality of the environment, and to adjust the energy structure, Electrical Energy Substitution Policy was adopted as a national strategy with an aim to promote the consumption of electricity.

In 2016, the Guideline on Promoting Electrical Energy Substitution was published by China National Energy Administration. This document proposed to substitute coal and oil with electricity in four key areas, including space heating in northern China, manufacturing, transportation, and power supply \& consumption. Among them, the clean space heating sector would increase an average of 22 billion kWh of new electricity consumption each year by electric heating, accounting for about $25 \%$ of total target for Electrical Energy Substitution program. 
The Coal to Electricity Transformation was more widely known in the space heating industry than the Electrical Energy Substitution policy. The Coal to Electricity Transformation replaces coalfired boilers with ASHPs and GSHPs, in some cities, including regenerative electric boilers, but this program prohibited direct heating types of electric heater.

Local authorities were responsible for some preliminary work such as site choosing, land requisition, and demolition. In Beijing, supportive power grid projects for Coal to Electricity transformation lower than $10 \mathrm{KV}$ would get 30\% subsidy of the initial investment, 12,000 CNY subsidies per household for purchasing heating equipment and 0.1 CNY / kWh electricity price subsidy for operating in the heating season. As of 2017, there were more than 1.1 million households that had completed Coal to Electricity renovation in Beijing.

Although the Coal to Electricity policy got some immediate and short-term results, it was still in dispute on the cleanness of electricity and the sustainability of subsidies. Because power production was another vital pollution source in China. As shown in Figure 7, 64\% of electricity came from coal combustion[26] in 2016.

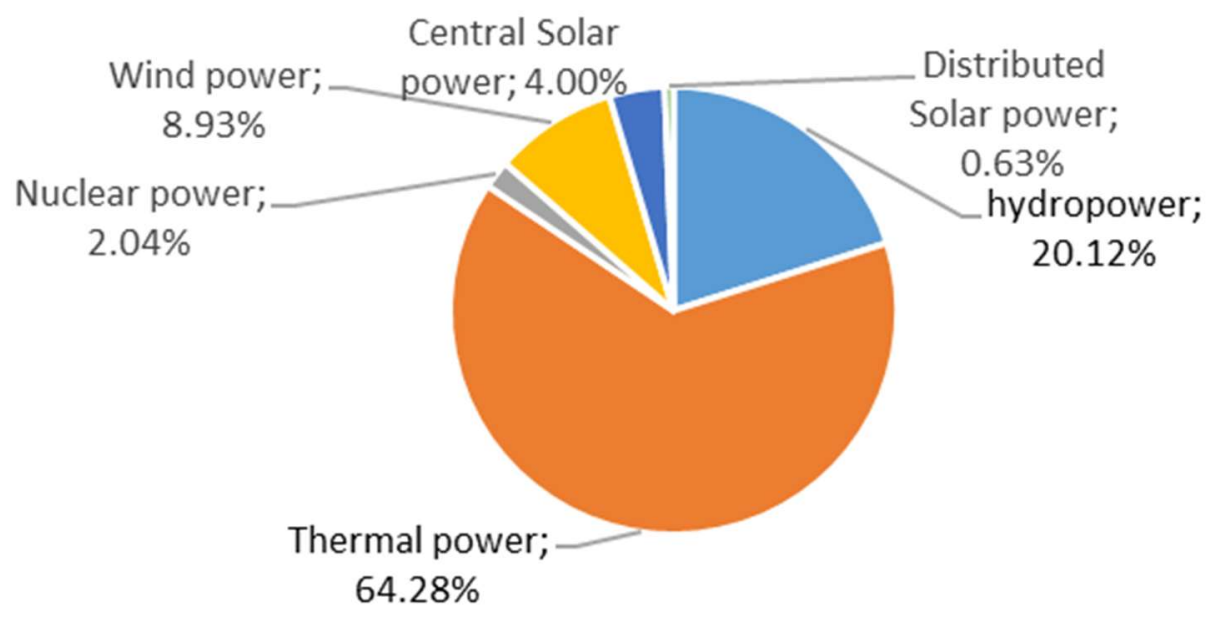

Figure 7 Power Source Structure of China in 2016

Another disputation was the heavy financial burden. Taking Beijing as an example, thanks to the developed economy of Beijing, the government's financial capacity was strong enough to pay an average of 24,000 CNY subsidies per household for purchasing clean heating equipment. It was expected that there would be another 1.1 million households completing Coal to Electricity transformation at the end of 2020. Assuming a maximum subsidy for 10 thousand $\mathrm{kWh}$ per household for the operating of electric heating equipment, the government would need 49 billion CNY annually.

\subsection{Coal to Gas Transformation}


The Coal to Gas Transformation Program refers to the substitute of coal with natural gas. The gas heating methods mainly include three types: gas-fired cogeneration, regional gas-fired boilers, and household gas boilers[27].

Coal to Gas Transformation for power plants was first implemented in Beijing and quickly adopted by other cities. Since 2009, Beijing had completed Coal to Gas Transformation. At present, the four major coal power plants in urban areas had all been changed to gas boilers. Coal to Gas transformation program in suburban and rural areas was also progressing.

As of the end of 2016, the heated area by natural gas in northern China was approximately 2.2 billion $\mathrm{m}^{2}$, accounting for $11 \%$ of the total heated area. The natural gas consumption was 25.9 billion $\mathrm{m}^{3}$, accounting for $26 \%$ of the natural gas consumption in northern China. The proportion of natural gas consumption for space heating in northern China was generally low. Only urban areas in Beijing and Tianjin accounted for a relatively high proportion, of which about $80 \%$ in Beijing and about 50\% in Tianjin in 2016.

In 2017, the Coal to Gas transformation in Hebei Province had caused a natural gas shortage in entire North China. The gas shortage even across the whole country in the winter of 2017. The rapid growth in demand for natural gas had broken the balance between supply and demand, resulting in a rise in gas prices. Inadequate gas supply, shortage of subsidy, and imperfect infrastructure prevented the continued implementation of the Coal to Gas transformation. Hebei government had announced that no new Coal to Gas transformation project in rural areas would be added in 2018.

\subsection{Rural infrastructure}

Improvements in rural infrastructure have created opportunities for the application of SDH. The Chinese government has paid considerable attention to the issue of "Agriculture, Rural areas, and Farmers." In recent years, it has promulgated a series of policies to support and benefit farmers, including increasing the intensity of rural infrastructure construction. In 2013, China State Council stated that "improving the public service mechanism in rural areas shall actively promote the balanced allocation of public resources in urban and rural areas, strengthen rural infrastructure construction, and promote the construction of rural ecological civilization." District heating in rural areas can significantly improve people's living standard and achieve urban-rural coordinated development in northern China heating area.

Although rural areas have better conditions for SDH in terms of land availability, they also face greater policy obstacles. In 2006, China State Council issued the third edition of Outline of the National Plan for Overall Land Use (2006-2020) and proposed six constraints and nine expected indicators for the goals and tasks of land use in the next 15 years. The regulations were strengthened in 2016: By 2020, the total farmland in the country will be 120 million ha and the 
essential farmland protection area will be 103 million ha. Considering that China's land is stateowned, changing the nature of the land, especially arable land, will pay large communication costs and financial costs. Therefore, for the site selection of a SDH project, it is necessary to conduct a site survey in the early planning and try to avoid the choice of farmland to install collectors.

\subsection{Economic feasibility}

The most attractive advantage of SDH for end users is the great operation cost savings. In a combination system of solar thermal and a gas boiler, solar can contribute with 66\% energy cost savings by saving gas consumption[28] in the Hebei area compared with a single gas boiler. For a solar combined with an ASHP heating system, solar can contribute $45 \%$ energy cost savings in Xi'an City[29] compared with a single ASHP.

Based on Danish experiences on SDH application, the total initial investment for a SDH plant comprises system design and optimization, land, solar collectors, installation and commissioning, heating pipe network, heat exchanger units (including pumps, expansion vessels, control, and other accessories), storage, and control system. The operating cost depends on natural gas price, electricity price, time dependency of the electricity price, capacity dependency of the electricity price, subsidies or tax reductions for renewable energy, and price of labour power.

To discuss the economic feasibility of SDH in China, a comparison of the initial investment and operating cost for a SDH plant between Denmark and China is listed in Table 3.

Table 3 A comparison of the initial investment and operating cost for a SDH plant between Denmark and China

\begin{tabular}{|c|c|c|c|}
\hline Price & Unit & Denmark & China \\
\hline Electricity & CNY / KWh & 2.41 & $0.4^{\sim} 0.7$ \\
\hline Gas & CNY / KWh & 0.69 & $0.16^{\sim} 0.48$ \\
\hline Oil & CNY / L & 11.6 & 7.39 \\
\hline Heat price & CNY / KWh & $0.16^{\sim} 0.93$ & $0.08 \sim 0.16$ \\
\hline Land & $\mathrm{CNY} / \mathrm{m}^{2}$ & $\begin{array}{l}\text { Agricultural land, } 13 \text {; } \\
\text { Permanent grassland, 6.6[30] }\end{array}$ & $\begin{array}{l}\text { Average, } 4500 \text {; Commercial, } 7600 \text {; } \\
\text { Residential, } 7080 \text {; Industrial, 800;Farm } \\
\text { land, } 150 \sim 300[31]\end{array}$ \\
\hline Labour power & CNY / hour & $327[32]$ & $240[33]$ \\
\hline Solar collector* & $\mathrm{CNY} / \mathrm{m}^{2}$ & $1540^{\sim} 1927$ & $400 \sim 600$ \\
\hline
\end{tabular}

* The prices of solar collectors are based on flat plate solar collectors.

High prices for heat, electricity and fossil fuel are essential reasons why Denmark can successfully implement SDH. At the same time, low land prices make it possible to install collectors with a large area directly on ground (even farm land). These favorable conditions are not available in China. China's welfare heating system makes heat price very low, the prices of various energy 
are relatively low. However, the land is costly. These factors have significantly reduced the economics of SDH in China.

China's strength lies in its relatively low labour costs and cheap collectors. From Danish experiences, the collector field cost has the most impact on the final heat price and accounts for most of the initial investment. When solar fraction is between $20 \%-40 \%$, the cost of solar collector field shares $85 \%-64 \%$, but the land cost only shares less than $2 \%[20]$. Therefore, making the collector field produce the most heat, thus minimizing operating costs, is a meaningful way to ensure the economics of SDH. The heat production of the collector field is related to the efficiency of the collector, the layout of the collector field, the solar radiation and the solar fraction (SF). In which, the solar radiation and the SF of the system have the most significant impact on the economics of a particular project.

\subsection{Solar radiation}

China has abundant solar resources, the annual solar radiation in China is between 930 and $2330 \mathrm{kWh} / \mathrm{m}^{2}$, corresponding to 2.5 to $6.4 \mathrm{kWh} / \mathrm{m}^{2}$ daily solar radiations [34].
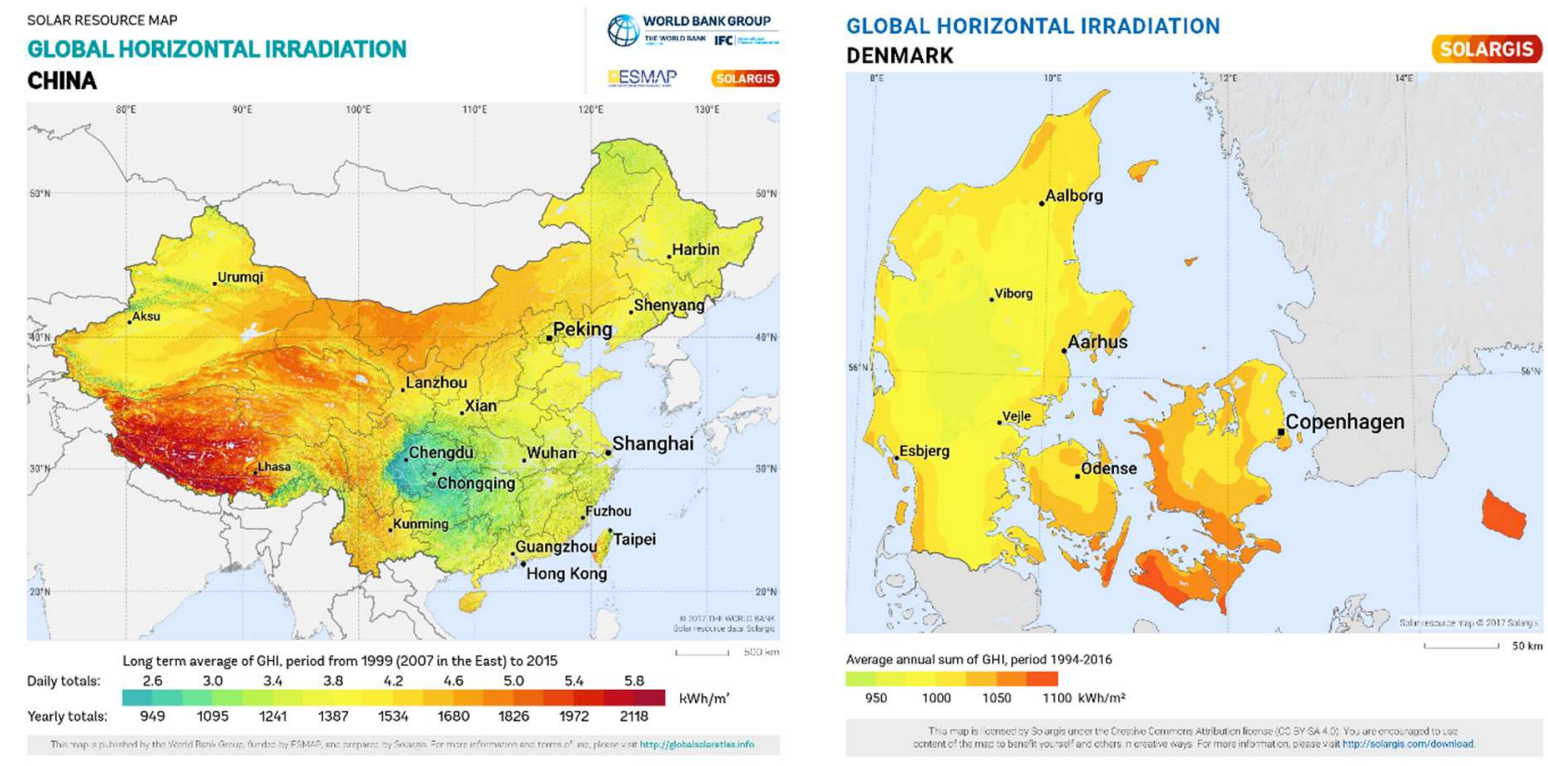

Solar resource map @ 2018 Solargis

Figure 8 Global horizontal irradiation in China and in Denmark

Table 4 China National total horizontal solar radiation level and regional distribution[34]

\begin{tabular}{llll}
\hline & Total horizontal & Fraction of & \\
Radiation level & solar & Region \\
& radiation $\left(\mathrm{KWh} / \mathrm{m}^{2} . \mathrm{a}\right)$ & territory area & \\
& &
\end{tabular}




\begin{tabular}{|c|c|c|c|}
\hline Most rich (I) & $\geq 1750$ & 22.8 & $\begin{array}{l}\text { West of Inner Mongolia; West of Gansu; Tibet } \\
\text { and Qinghai, East of Xinjiang; Ganzi of Sichuan } \\
\text { province }\end{array}$ \\
\hline Better rich（II） & $1400 \sim 1750$ & 44.0 & $\begin{array}{l}\text { Xinjiang; East of Inner Mongolia; Northeast of } \\
\text { China; Beijing; Tianjin; Hebei; Henan; Shanxi; } \\
\text { East of Shandong; North of Shanxi; Ningxia; } \\
\text { Gansu; Hainan; Yunnan }\end{array}$ \\
\hline Rich（III） & 1050 1400 & 29.8 & $\begin{array}{l}\text { North of Inner Mongolia; South of Shandong, } \\
\text { Shanxi, Shanxi(Xian); East of Gansu, Yunnan; } \\
\text { Hunan; Hubei; Guangdong; Guangxi; Fujian; } \\
\text { Jiangxi; Zhejiang; Anhui; Jiangsu; Henan }\end{array}$ \\
\hline General (IV) & $<1050$ & 3.3 & Sichuan; Chongqing; Guizhou \\
\hline
\end{tabular}

Figure 8 left shows that solar radiation resource is rich in most places in China. The highest annual global radiation is $2330 \mathrm{kWh} / \mathrm{m}^{2}$ in Tibet. Figure 8 Global horizontal irradiation in China and in Denmark

Table 4 shows the places with rich solar radiation source mainly locate in the cold regions of China with a large heat demand. Therefore, solar heating systems have a considerable potential in the severe cold and cold regions of China [12].

As a comparison, the average annual global radiation in Denmark was $962 \mathrm{KWh} / \mathrm{m}^{2}$ from 2006 to 2010[35], shown in Figure 8 right. The average radiation in north western China is almost twice of that in Denmark. Stronger solar radiation helps SDH contribute more free heat to a district heating network with the same collector installation area, which in turn increases the economics of SDH.

\subsection{Solar Fraction}

The solar fraction (SF) is the share of heat delivered to the district heating network that is covered by solar heat. A higher SF indicates that the system produce more solar heat, but it will also increase the collector installation area and the capacity of the corresponding heat storage facility, thus increasing initial investment. In the 104 Danish SDH plants in operating, the average SF is $20 \%[20]$. For different regions of China, due to different solar radiation, different energy prices, heat prices and land prices, it is necessary to optimize the system design in the early planning and design phase of the project to identify the best cost-effective SF.

\section{3. $\mathrm{LCOH}$}

A comprehensive index should be used to evaluate the economic performance for a hybrid 
energy heating plant. According to the guideline published by IEA Task 54[36], levelized cost of heat $(\mathrm{LCOH})$ is a useful indicator to estimate the cost of the heat generated by the entire solar assisted heating system in a life cycle, with the consideration of both initial investment and operation \& maintenance cost. Zhiyong Tian used LCOH to optimize the thermo-economic performance of a hybrid SDH plant with FPC and PTC collectors[37], which shows the LCOH is a useful indicator to optimize the design and operation for a hybrid energy heating system.

The equation recommended by IEA Task 54[36] to calculate LCoH value is shown in Equation 1:

$$
L C o H=\frac{I_{0}-S_{0}+\sum_{t=1}^{T} \frac{C_{t}(1-T R)-D E P_{t} \cdot T R}{(1+r)^{t}}-\frac{R V}{(1+r)^{T}}}{\sum_{t=1}^{T} \frac{E_{t}}{(1+r)^{t}}} \quad \text { Equation } 1
$$

Where, $\mathrm{LCoH}$ : the levelized cost of heat, $\mathrm{CNY} / \mathrm{kWh}$; $I_{0}$ : the initial investment for the whole system, CNY; $S_{0}$ : subsidies and incentives, CNY; $C_{t}$ : operation and maintenance costs (in year t), $\mathrm{CNY}$; $T R$ : the tax rate, \%; $D E P_{t}$ : the asset depreciation (year $\mathrm{t}$ ), CNY; $R V$ : the residual value of system; $E_{t}$ : the total energy demand (in year t), kWh; $r$ : the discount rate, \%; $T$ : the period of analysis, year.

For a SDH plant, a large area of solar collectors needs to be installed, the land rent $p_{\text {land, }}$ $\mathrm{CNY/year}$, should be counted in the calculation as a part of the operation fee, and the total cost including taxes will be considered, then the Equation 1 can be simplified as Equation 2:

$$
L C o H=\frac{I_{0}-S_{0}+\sum_{t=1}^{T} \frac{\left(C_{t}+p_{\text {land }}\right)}{(1+r)^{t}}-\frac{R V}{(1+r)^{T}}}{\sum_{t=1}^{T} \frac{E_{t}}{(1+r)^{t}}}
$$

Equation 2

For large-scale systems in Denmark with a collector installation area larger than $10,000 \mathrm{~m}^{2}$, the average $\mathrm{LCoH}$ for diurnal storage is $0.28 \mathrm{CNY} / \mathrm{kWh}$. Moreover, for even larger systems (the collector installation area $>50,000 \mathrm{~m}^{2}$ ) with seasonal heat storages, the average $\mathrm{LCOH}$ is $0.38 \mathrm{CNY}$ / kWh[3]. For a different region with different energy structure, a LCoH curve can be drawn with the SF changing from $0 \sim 100 \%$. The optimum SF when the system achieves the lowest LCoH can be identified with this method.

\subsection{Technical feasibility}

Successful practice of SDH in Denmark has shown the technical feasibility even in a climate condition with lower solar radiation and far more cloudy days than most of the heated areas in China. There are design tools[38], guidelines[21], and knowledge sharing programs between China and the frontrunner Denmark[17]. From Danish experiences, lower service temperature of district heating networks, high-performance flat plate solar collectors, and seasonal heat storage are the 
key technical factors for the success of SDH.

\subsection{Service temperature}

The temperature of the supply and return water in centralized heating systems in Chinese cities is generally higher $\left(\mathrm{T}_{\text {supply }}>90^{\circ} \mathrm{C}, \mathrm{T}_{\text {return }}>50^{\circ} \mathrm{C}\right)$ in primary pipeline networks[39]. It is difficult for solar heat to be connected directly into existing heating pipeline networks without heat pumps or reheat devices. Also, space heating is mandatory in heating season as a livelihood project in China, but there is no space heating demand in the rest of the year. That means a waste of solar energy in summer and an increase in the payback time for SDH. Therefore, to make full use of solar energy and to improve annual SF, a seasonal heat storage facility is necessary.

In addition to the lack of development of pipeline network systems, the construction of smart energy systems is also lagging in China, which limits the application of hybrid energy sources in heating plants.

Centralized heating in rural China is still in its infancy. Rural households have mostly independent household heating, and the heating temperature is generally low. According to a survey on existing household space heating systems in Beijing rural areas in 2017[40], shown in Table 5, the average temperature of the forward water was lower than $50^{\circ} \mathrm{C}$. The lower service temperature for space heating creates a suitable condition for solar thermal and the integration of ASHP and GSHP systems.

Table 5 A service comparison for existing household space heating systems in Beijing rural areas

\begin{tabular}{lll}
\hline & Supply water & Fluctuation range of indoor temperature \\
\hline ASHP + floor heating & $30^{\sim} 40^{\circ} \mathrm{C}$ & $<2^{\circ} \mathrm{C}$ \\
\hline ASHP + Radiator & $40^{\sim} 45^{\circ} \mathrm{C}$ & $<3^{\circ} \mathrm{C}$ \\
\hline Regenerative Electric heating & $50^{\sim} 65^{\circ} \mathrm{C}$ & $>6^{\circ} \mathrm{C}$ \\
\hline Electric Boiler + Radiator & $/$ & $<3^{\circ} \mathrm{C}$ \\
\hline Electric floor heating & $/$ & $<2^{\circ} \mathrm{C}$ \\
\hline Gas boiler + floor heating & $40^{\sim} 50^{\circ} \mathrm{C}$ & $<2^{\circ} \mathrm{C}$ \\
\hline Gas boiler + radiator & $40^{\sim} 50^{\circ} \mathrm{C}$ & $<2^{\circ} \mathrm{C}$ \\
\hline Solar + ASHP & $30^{\sim} 40^{\circ} \mathrm{C}$ & $<2^{\circ} \mathrm{C}$ \\
\hline
\end{tabular}

\subsection{Solar collectors}

Household solar heating systems mostly used all-glass evacuated tube collectors (ETC) in China in the past. The lifespan of ETC is about ten years theoretically. However, in practices, bursting and overheat of all-glass ETCs were severe, which resulted in massive operation and maintenance work. Many all-glass ETCs broken within the first year of its installation. The 
Investigation Report[10] suggested that flat plate collectors (FPC) with a simple structure, long service life and low maintenance rate should be selected for solar heating. Advantages of FPCs are not only durability, security, low installation cost[41] but also their high efficiency for district heating[42]. Figure 9 shows that $97 \%$ of existing SDH projects in EU countries used FPCs.

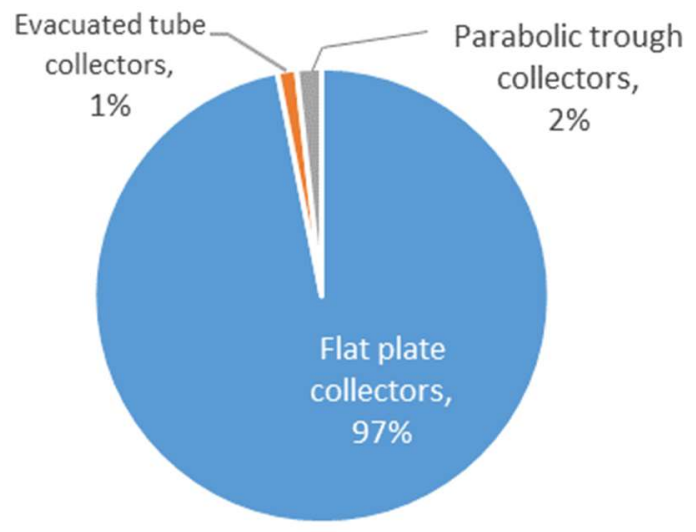

Figure 9 FPC dominates the installation in SDH plants in existing 199 heating plants in Europe.

The difference is that large-sized FPCs are used in SDH plants in Denmark, the area for a single FPC is between $12^{\sim} 15 \mathrm{~m}^{2}$. However, the mainstream FPC used in solar water heating systems in China is small-sized with an area of $2 \mathrm{~m}^{2}$. Table 6 shows the performance difference between these two types of FPC. It can be seen that the large-sized FPC has a better thermal performance so that it produces more heat with the same area. Large-sized FPC can also save on pipe fittings and installation costs.

Table 6 The performance comparison between a typical Danish and Chinese FPC product[43]

\begin{tabular}{|c|c|c|c|}
\hline & Unit & large-sized FPC & small-sized FPC \\
\hline Area & $\mathrm{m}^{2}$ & $12^{\sim} 15$ & 2 \\
\hline The transmittance of glass cover & - & 0.93 & 0.89 \\
\hline The absorption of coating & - & 0.95 & 0.92 \\
\hline The peak collector efficiency & - & 0.82 & 0.75 \\
\hline $\begin{array}{r}\text { The heat loss coefficient of collector at ambient } \\
\text { temperature }\end{array}$ & $\mathrm{W} / \mathrm{m}^{2} \cdot \mathrm{k}$ & 3 & 3.4 \\
\hline
\end{tabular}

However, with the increasing demand for high-performance FPCs by SDH, some backbone enterprises in China have developed large-sized FPCs. These high-performance FPCs can significantly reduce the initial investment and heat price of SDH.

\subsection{Seasonal heat storage}


There is still a lack of sufficient theoretical research and practical experience on seasonal heat storage technology in China. However, a lot of experience and lessons in the application of GSHPs for space heating have been gained.

In the past decade, part of the local Chinese government in cold northern areas promoted GSHP as a renewable energy heating source. The heated area by GSHP heating system increased quickly till 2015. Only in Shenyang City, the heated area by GSHPs reached to 59.41 million $^{2}$ in 2012, accounting for nearly $1 / 3$ of the city's total heated area[44]. There were many residential communities heated by GSHPs could not reach the design indoor temperature because of a longterm imbalance between heat injection and extraction in recent years, which results in a gradual decrease of the soil temperature year by year. It is for this reason that the number of new GSHP heating systems begun to decrease.

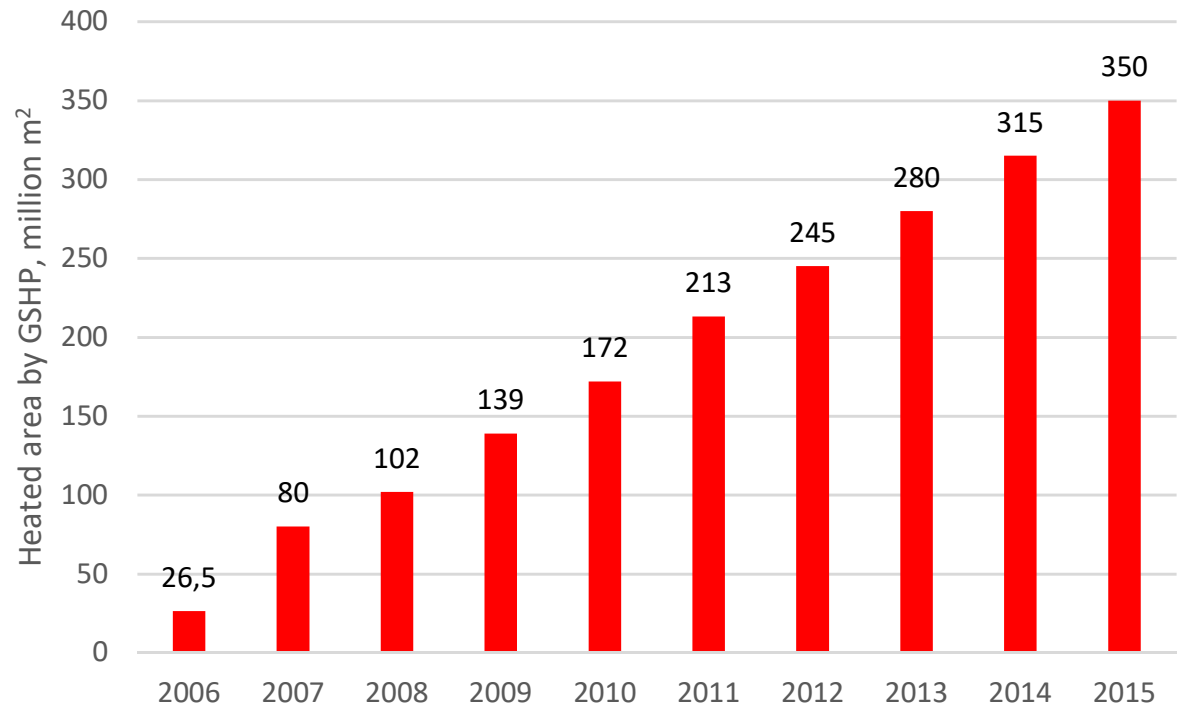

Figure 10 Building area heated by GSHP technology in China[44]

A GSHP can also be used as a seasonal heat storage solution. An auxiliary solar collector field can be added to those GSHP systems not functioning correctly to form a combined heating system. This combined heating system can be controlled by valves to recharge heat into the soil in summer by the solar collector field, consequently the soil temperature is increased and the heating capacity of the GSHP system is restored. Besides, this combination of GSHP and solar thermal can improve system energy efficiency and reduce the operating cost.

\subsection{Market feasibility}

Northern China owns the necessary conditions for the implementation of SDH with a developed district heating network. With the energy efficiency renovation for existing buildings 
and clean energy transformation of existing district heating systems, development of lowtemperature heating technology and more stringent restrictions to coal-fired boilers, heating enterprises must actively look for clean energy alternative to fossil energy.

According to the clean heating action plan, the building area heated by solar thermal will achieve 50 million $\mathrm{m}^{2}$ in 2021[8], accounting for $0.18 \%$ of the total heated area. Based on the research findings on the potential for solar thermal in future energy systems in EU countries[45], the overall solar thermal potential across EU countries is in the range of $3 \%{ }^{\sim} 12 \%$ of the total heat production[46]. Considering the vast heating demand and the cheap land resources in north-west areas in China, the solar heated area would achieve 756 million $\mathrm{m}^{2}$ with an assumption of $3 \%$ of the total heat demand.

In China, the city is dominated by large-scale centralized heating, while the rural areas are dominated by decentralized household heating. It is necessary to discuss these two distinct space heating markets separately.

\subsection{Urban market}

As of the end of 2017, the centralized heated area of northern China's cities was 8.31 billion $\mathrm{m}^{2}$. The centralized heated area increased rapidly in the past decades. As shown in Figure 11, the centralized heated area in 2017 was 10 times than that in 1997.

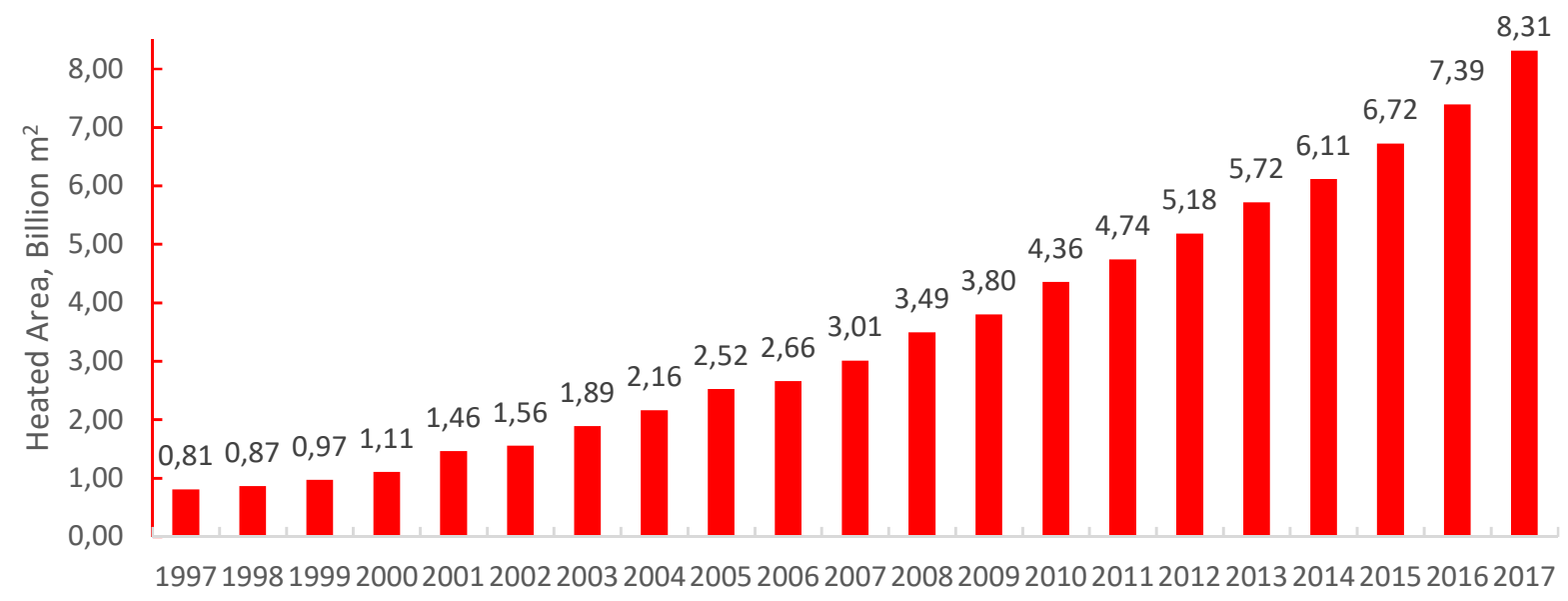

Figure 11 The centralized heated area in urban areas in China in 1997-2017 [47]

Figure 12 shows that coal cogeneration and large coal boilers were the primary sources of heat, accounting for $81 \%$ of the total heated area. 


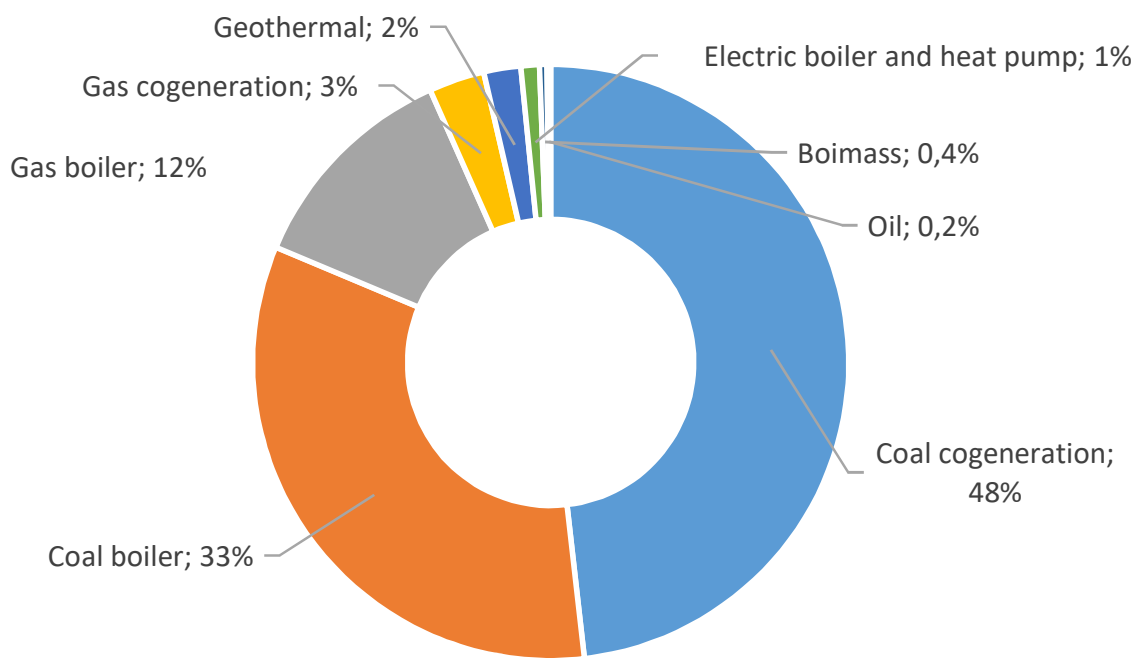

Figure 12 The heat source structure of the urban centralized heating in China in 2016[48]

At present, almost all of the heat stations in cities such as Beijing and Tianjin use a single energy source: coal or natural gas. However, from the perspective of reducing operating costs and reducing pollutant emissions, hybrid-energy systems are inevitable. The existing large-scale heating facilities in cities create conditions for the use of renewable energy such as solar energy. Figure 13 shows that three provinces with the highest market potential are Shandong, Liaoning, and Hebei.

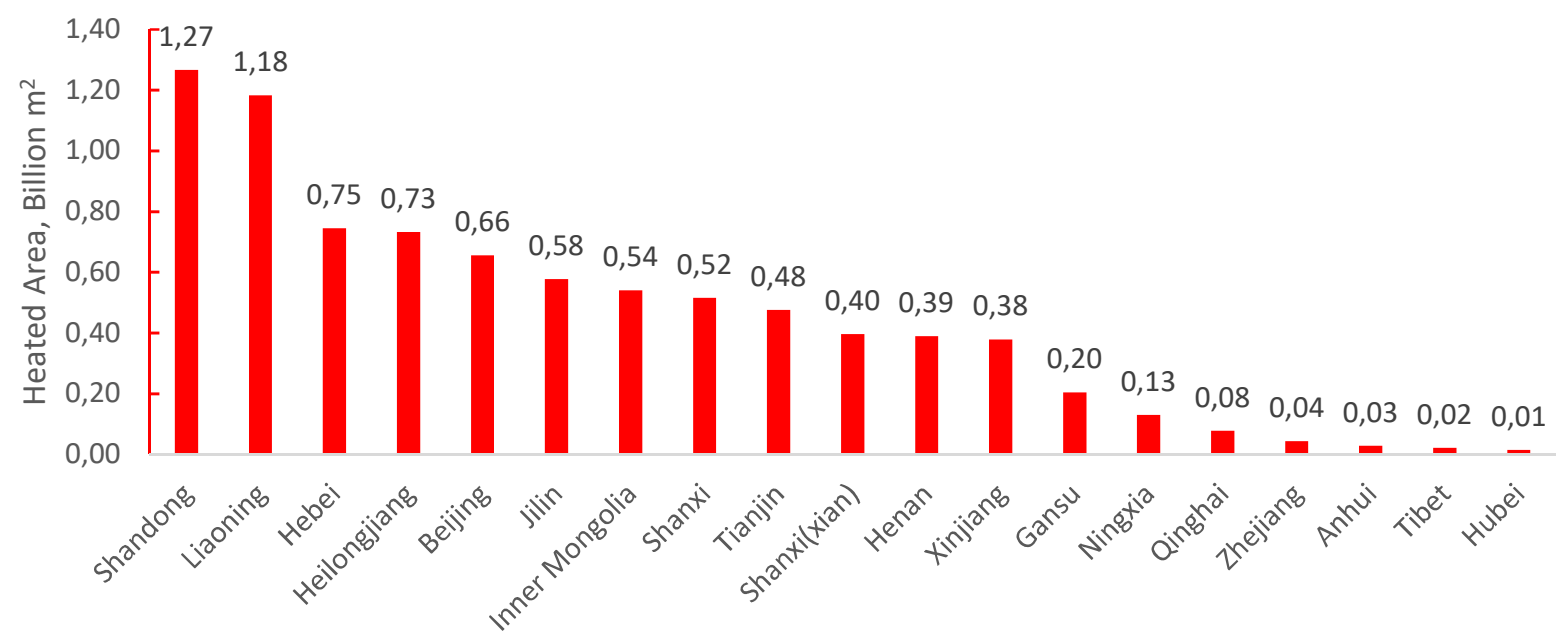

Figure 13 The centralized heated area by provinces in 2017[47]

The urban area has a large population density, high land price, and limited installation space of solar collectors. It is not wise to choose urban centralized heating as the start for SDH. However, 
the heat demand in urban area is huge and the users are concentrated. The economic benefit and environmental benefit from SDH are more significant. There are two types of systems, centralized SDH system and distributed SDH system[49] [50]. For an urban area, distributed SDH would be a choice.

\subsection{Rural market}

As shown in Figure 14, the northern rural heating mainly relies on the heated brick bed, household coal stove, gas stove, electric heating and solar assisted biomass boiler heating in some developed rural area around Beijing and Tianjin. Some rural areas also developed small district heating systems[51].

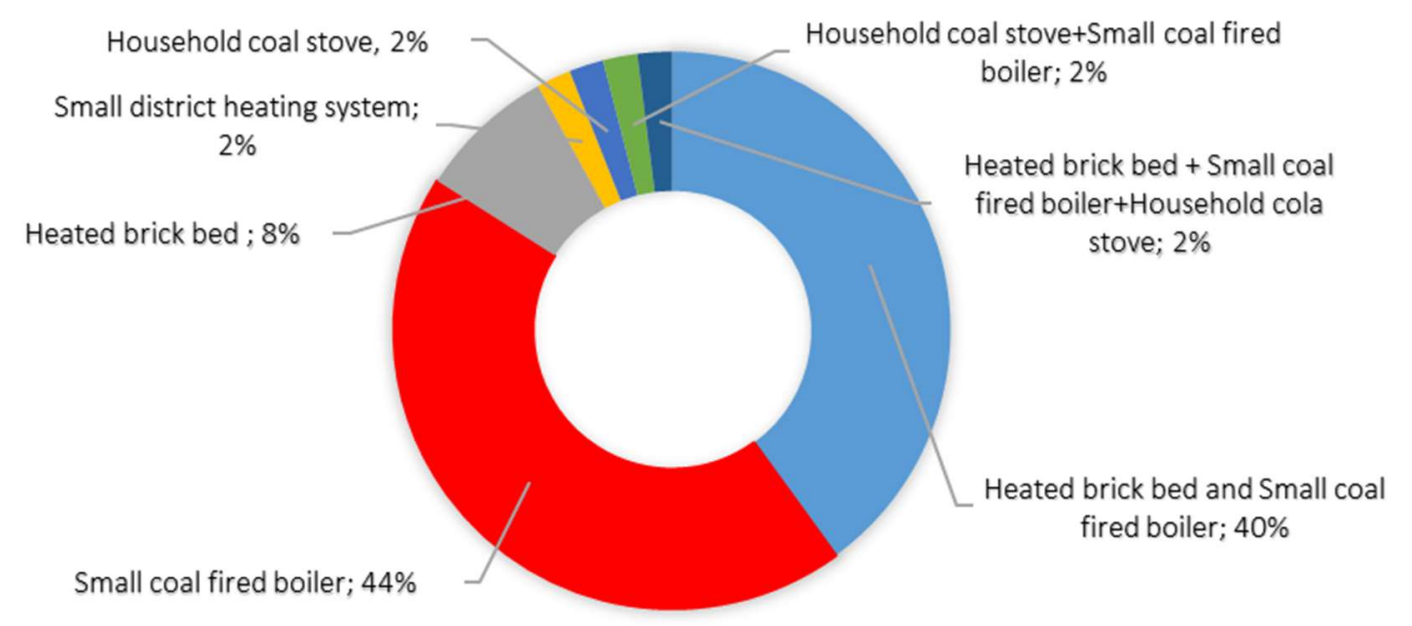

Figure 14 Rural Space Heating Technologies in North China

There are many deficiencies in existing heating solutions in north China rural areas, such as low indoor temperature, massive energy consumption, severe pollution and so on. The energy utilization rate of a heated brick bed is about $60 \%$, a stove is only $40 \%$ [52]. While there is no insulation measure for heating pipelines, the heat loss of pipelines is considerable. Heating safety is also not guaranteed. The improper operation or design easily lead to toxic gas leakages, and even explosion accident and gas poisoning.

The clean heating movement is not only to resolve the air pollution problem but also to improve the living condition for rural residents. Relative to the cities, the living conditions in rural areas of China are poor, mainly due to the backwardness of infrastructure, low level of public management, lack of public service, and lack of awareness of environmental protection. If district heating is used in rural areas, the quality of life of rural residents will be significantly improved. 
The field survey found that farmers not only accepted district heating but also were willing to participate in the construction and management of heating plants. $98 \%$ of farmers believe that there are many drawbacks in the current heating solutions. Moreover, farmers think that there are many advantages of district heating, including less heating costs, higher heating safety, and better service. At present, many young and middle-aged rural people are working in cities, leaving behind many elder adults and children. District heating can significantly facilitate their daily lives.

Rural areas with better infrastructure are suitable for the priority development of SDH. There were a total 715 million $\mathrm{m}^{2}$ of centralized heated area in towns and villages in rural North China in 2017. Low operating costs can be achieved by adding solar collectors and heat storage systems to existing central heat stations. Those areas that lack infrastructure need more subsidies from the government. As shown in Figure 15, regarding the existing centralized heating pipeline network in rural areas, Shandong province is far more developed than the other provinces.

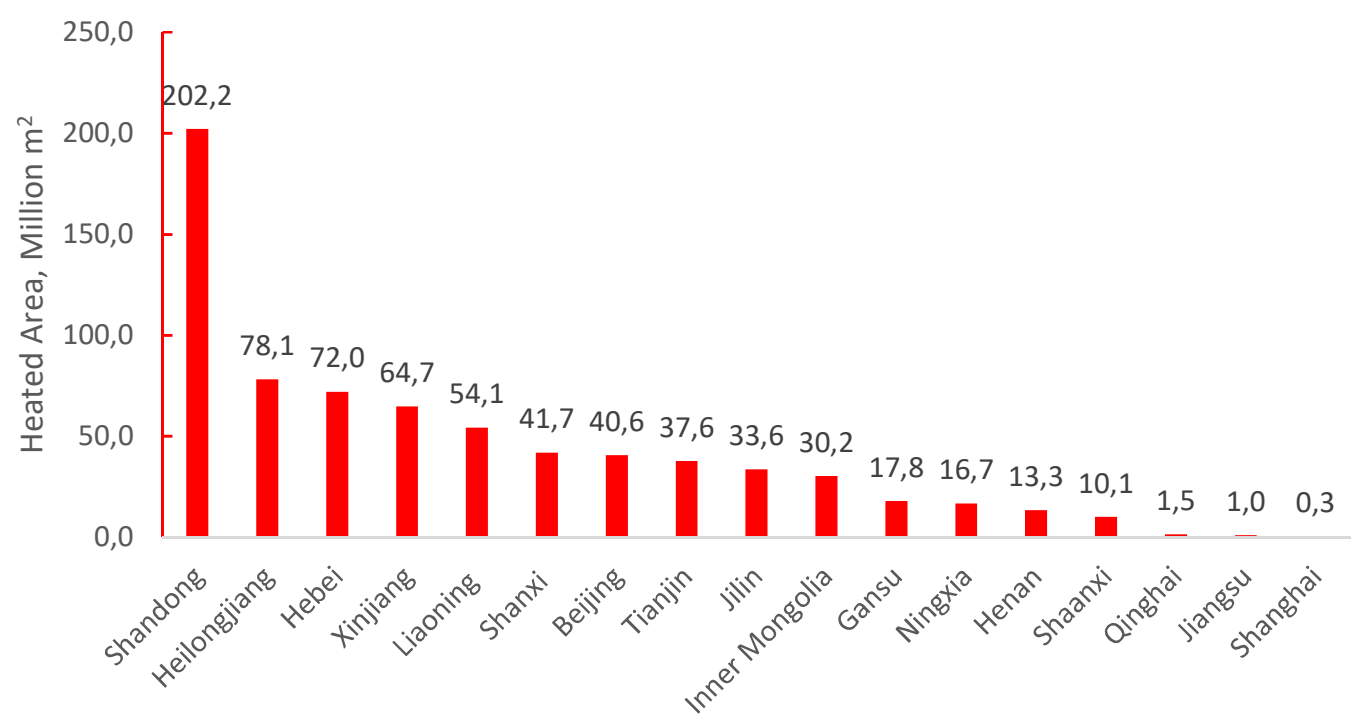

Figure 15 The centralized heated area in towns and villages in China in 2017 [47]

\subsection{Special market}

There are some areas with strict environmental protection policy but without enough gas and electricity supply for space heating demand. There are few choices for clean heating except for solar thermal. Therefore, at the beginning phase for SDH in China, the most suitable area for developing SDH is the area with abundant solar resources, more extended heating period, cheap lands available, limited power grids, and limited gas pipeline network coverage, such as Tibet, Gansu, Qinghai Province. 


\subsection{Development strategy}

Based on the PEST analysis and the background information, a SWOT analysis is conducted to summarize the pros and cons, the opportunities and challenges, and the development strategies of SDH in China.

\subsection{SWOT analysis}

The purpose of the SWOT analysis is to identify critical items for the development of SDH in China, which involves establishing priorities for action, and to prepare strategic options by strengthening the positive points and improving the weaknesses to cope with threats.

Table 7 The SWOT matrix for SDH in China

\begin{tabular}{|c|c|c|}
\hline & Strengths & Weaknesses \\
\hline & $\begin{array}{l}\text { 1. High efficiency } \\
\text { 2. High flexibility } \\
\text { 3. Low operating cost } \\
\text { 4. Easy operation and } \\
\text { maintenance } \\
\text { 5. Emission-free } \\
\text { 6. } 100 \% \text { renewable and local }\end{array}$ & $\begin{array}{l}\text { 1. Land occupation } \\
\text { 2. Complex system } \\
\text { 3. High initial investment } \\
\text { 4. Heat production is affected by the } \\
\text { weather }\end{array}$ \\
\hline Opportunities & Opportunity-strength strategies & Opportunity-weakness strategies \\
\hline $\begin{array}{l}\text { 1. Favorable policies } \\
\text { 2. Clean heating } \\
\text { renovation } \\
\text { 3. Rural infrastructure } \\
\text { construction } \\
\text { 4. Large-scale existing } \\
\text { GSHP heating system }\end{array}$ & $\begin{array}{l}\text { 1. Special areas } \\
\text { 2. Promote a smart district } \\
\text { heating system in rural } \\
\text { villages } \\
\text { 3. Influence district energy } \\
\text { planning for a rural area } \\
\text { 4. Promote the renovation of } \\
\text { the existing GSHP heating } \\
\text { system }\end{array}$ & $\begin{array}{l}\text { 1. Rural areas with district heating } \\
\text { network } \\
\text { 2. Use domestically-made high- } \\
\text { performance FPCs } \\
\text { 3. Install collectors on roofs, parking } \\
\text { lots or overhead structures. } \\
\text { 4. Optimize the system and set a } \\
\text { reasonable SF } \\
\text { 5. Seasonal heat storage }\end{array}$ \\
\hline Threats & Threat-strength strategies & Threat-weakness strategies \\
\hline $\begin{array}{ll}\text { 1. } & \text { Heat pumps } \\
\text { 2. } & \text { Regenerative electric } \\
\text { boilers } \\
\text { 3. Geothermal } \\
\text { 4. Nuclear heating }\end{array}$ & $\begin{array}{l}\text { 1. To develop hybrid energy } \\
\text { systems with heat pumps, } \\
\text { gas boilers, and electric } \\
\text { boilers. } \\
\text { 2. Use LCoH to evaluate the } \\
\text { economic performance }\end{array}$ & $\begin{array}{l}\text { 1. R \& D on high energy density heat } \\
\text { storage technology } \\
\text { 2. Improve the efficiency of } \\
\text { collectors }\end{array}$ \\
\hline
\end{tabular}


Table 7 shows that the current clean heating policy should be fully utilized to prioritize SDH in areas where resources are scarce, environmental requirements are strict and infrastructure conditions are better. It is necessary to actively promote renewable energy, hybrid energy and smart heating network in district energy planning.

China's land use costs are high. The availability of land for collector installation is a significant obstacle to the development of large-scale SDH. Therefore, collectors should be installed on roofs, parking lots or overhead structures as much as possible, meanwhile it is also vital to increase collector efficiency and the energy density of heat storage systems, to reduce collector costs and to optimize the system for the lowest heat price.

\subsection{Decision-making process}

For a potential SDH project, the decision-making process is drawn in Figure 16. From the process, economic performance is the core for choosing a SDH solution.

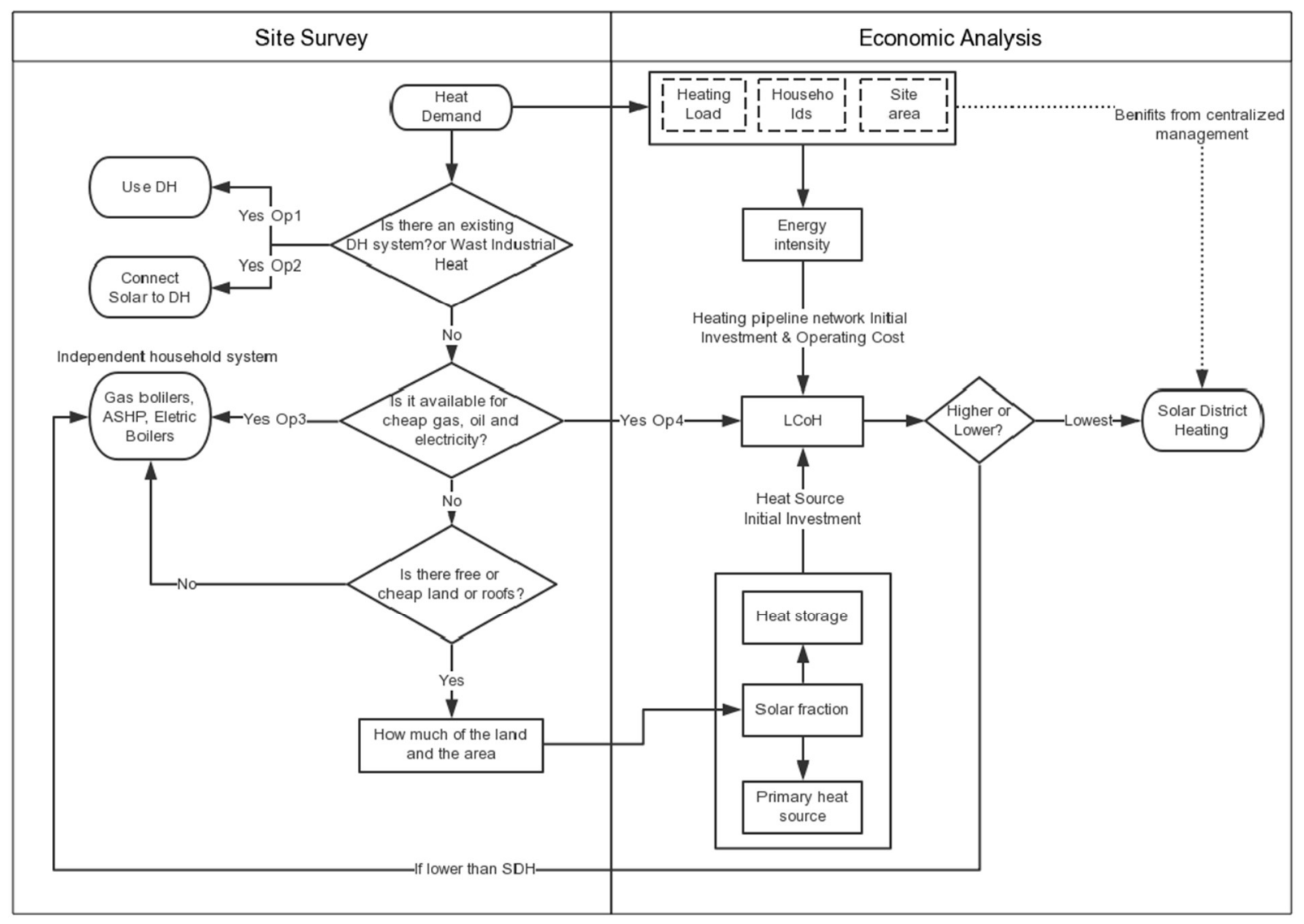

Figure 16 Decision-making process for a SDH project in the plan. 


\subsection{Roadmap}

Based on the SWOT analysis of SDH development in China, a roadmap for SDH development in China is proposed, as shown in Table 8. The roadmap takes into account experience of existing household solar heating projects in Beijing rural areas and the investigation on clean heating transformation in northern China. The roadmap suggests SDH should be developed in rural areas, small towns, and villages as a pilot demonstration stage to accumulate practical experience. Then the market would be expanded to industrial parks and some newly built large residential communities in urban suburbs. For the integration of solar heat with existing urban heating networks, which needs more theoretical research and demo projects to explore a technical path suitable for Chinese district heating networks.

Table 8 SDH development roadmap suggestion in China

\begin{tabular}{llll}
\hline Steps & Pilot demonstration & Technology accumulation & Technology innovation \\
\hline Year & 2017-2020 & 2021-2025 & 2026-2030 \\
\hline Target market & Rural area, small & Industrial parks, large & Small cities, integration with \\
& villages, towns & residential communities & existing heating network \\
\hline Technology & Solar + GSHP, Solar + & Low-temperature & System integration, large- \\
application & Tank Thermal Storage, & heating, remote & scale solar district heating \\
& high-performance flat & monitoring, seasonal heat & \\
& plate solar collector & storage & \\
\hline
\end{tabular}

\subsection{Conclusions}

Compared with the Coal to Gas and Coal to Electricity transformations, solar district heating (SDH) is the most potential technology to substitute fossil fuel entirely with the lowest operating cost in the long run, which means no or few subsidies for long-term operation. A PEST analysis and a SWOT analysis were conducted on SDH development in China based on the Danish experience.The SDH development strategies, roadmap, and decision-making process were summarized. The following conclusions are drawn:

1) SDH has a broad application prospect in China with abundant solar resources and favorable policies. The solar heated area can achieve 756 million $\mathrm{m}^{2}$ with an assumption of $3 \%$ coverage of the total heat demand of buildings.

2) High-performance flat plate collectors (FPCS) will increase the reliability and reduce the operation \& maintenance cost of SDH systems significantly.

3) A solar assisted GSHP system is a reliable solution as a form of SDH. An auxiliary solar collector field can be added to those GSHP systems not functioning correctly to improve the 
system efficiency and to reduce operating costs.

4) Particular areas with low population density, scarce resources, and strict environmental requirements, e.g., Tibet, should be given high priority for SDH.

5) Rural villages and small towns with better infrastructure, e.g., district heating networks, are the best target market for SDH in the next five years.

6) With the maturity of seasonal heat storage technologies and the accumulation of practical experience, SDH can be expanded to industrial parks, large residential communities in sparsely populated northwest China.

7) Integration of solar heat with existing heating networks in big cities with centralized heating will be a big challenge in the long run.

8) Land availability is a significant obstacle to the development of large-scale SDH. Therefore, collectors should be installed on roofs, parking lots or overhead structures as much as possible.

9) $\mathrm{LCoH}$ is an excellent comprehensive indicator to optimize the economics of SDH. For a specific potential SDH project, a LCoH curve can be drawn with a changing SF from $0 \sim 100 \%$ to identify the optimum SF with the lowest system $\mathrm{LCoH}$.

\section{Acknowledgments}

This research was supported financially by the International Copper Association and the International Metal Solar Industrial Alliance. The data presented in this study is used only for research purpose.

\section{Reference}

[1] J. Huang and $\mathrm{Y} . \mathrm{Xu}$, "The development status and trend of solar district heating in Europe," Constr. Sci. Technol., no. 4, pp. 63-69, 2017.

[2] A. Heller, "15 Years of R\&D in central solar heating in Denmark," Sol. Energy, vol. 69, no. 6 , pp. $437-447,2000$.

[3] W. Weiss and M. Spörk-Dür, "Solar Heat Worldwide 2018," Gleisdorf, Austria, 2018.

[4] A. D. Rosa, "The Development of a new District Heating Concept Network Design and Optimization for Integrating Energy Conservation and Renewable Energy Use,” Technical University of Denmark, 2012.

[5] M. G. Fernández, C. Roger-Lacan, U. Gährs, and V. Aumaitre, Efficient district heating and cooling systems in the EU, no. December. JRC, 2016.

[6] Planenergi, "Solvarme i Danmark 1988-2018," 2018. [Online]. Available: http://planenergi.dk/arbejdsomraader/fjernvarme/solvarme/solvarme-i-danmark-19882018/. [Accessed: 12-May-2018].

[7] F. M. Werner Weiss, Monika Spörk-Dür, "Solar Heat Worldwide-Global Market Development and Trends in 2016-Detailed Market Figures 2015 (2017 version)," http://www.iea-shc.org/solar-heat-worldwide, 2017. 
[8] National Energy Administration of China, "Clean Heating Plan in North China in Winter ( 2017 - 2021 ),’ Beijing, China, 2017.

[9] G. M. W. Group and B. O'Keef, "Burden of Disease Attributable to Coal-Burning and Other Air Pollution Sources in China," 2016.

[10] P. C. on H. U. of C. R. E. Society, "Investigation Report on Solar Heating Demonstration Project in Mentougou District of Beijing," Beijing, 2010.

[11] R. Zheng and Z. Yin, "Solar Thermal Heating and Cooling in China," in Renewable Heating and Cooling: Technologies and Applications, 2015, pp. 221-239.

[12] A. Zottl, R. Nordman, and M. Miara, "Benchmarking method of seasonal performance," 2012.

[13] I. Malenković, "Definition Of Performance Figures For Solar And Heat Pump Systems," Vienna, Austria, 2012.

[14] Natural Resources Canada, "Drake Landing Solar Community," www.dlsc.ca, 2018. [Online]. Available: https://www.dlsc.ca/index.htm. [Accessed: 13-May-2018].

[15] T. Nuytten, B. Claessens, KristofParedis, J. Bael, and D. Six, "Flexibility of a combined heat and power system with thermal energy storage for district heating," Appl. Energy, vol. 104, pp. 583-591, 2013.

[16] K. M. Luc, A. Heller, and C. Rode, "Flexibility of Large-Scale Solar Heating Plant with Heat Pump and Thermal Energy Storage," in ISES EuroSun 2016, 2016, p. 13.

[17] S. Furbo, J. Fan, B. Perers, W. Kong, D. Trier, and N. From, "Testing, Development and Demonstration of Large Scale Solar District Heating Systems," Energy Procedia, vol. 70, pp. 568-573, 2015.

[18] Danish Ministry of Energy Utilities and Climate, "Energy-for a green Denmark," Copenhagen, 2018.

[19] J. E. Nielsen, "A Booming Market for Solar District Heating Opportunities and Challenges," 2014.

[20] D. Trier, F. Bava, C. K. Skov, and S. S. Sørensen, "Solar District Heating Trends and Possibilities," 2018.

[21] P. A. Sørensen, J. E. Nielsen, R. Battisti, T. Schmidt, and D. Trier, "Solar district heating guidelines: Collection of fact sheets," 2017.

[22] F. J. Aguilar, Scanning the Business Environment, 1st THUS e. New York: Macmillan, 1967.

[23] F. T. Rothaermel, Strategic Management. McGraw-Hill, 2016.

[24] State Council of China, "Air Pollution Prevention And Control Action Plan 2013-2017." State Council of China, Beijing, 2013.

[25] Beijing Municipal Bureau of Statistics, "Investigation Report on Coal to Clean Energy for Beijing Residents," Beijing, China, 2017.

[26] China Electricity Council, "China's Power Industry Annual Development Report (2017)." 2017.

[27] B. Möller and H. Lund, "Conversion of individual natural gas to district heating: Geographical studies of supply costs and consequences for the Danish energy system," Appl. Energy, vol. 87, no. 6, pp. 1846-1857, Jun. 2010.

[28] Z. Chen, "Study On Combined Heating System Of Solar Energy And Gas Wall Hung Boilers In Baoding," University Of Hebei, 2014.

[29] Z. Shen and Y. Xuan, "Energy Consumption Analysis of Solar Assisted Air Source Heat Pump Heating and Hot Water System," Refrig. Air Cond., vol. 30, no. 5, p. 5, 2016. 
[30] European Commission, "Agricultural Land Prices and Rents data for the European Union," 2016.

[31] Department of Natural Resources Development and Utilization Ministry of Natural Resources of China, "The land price monitoring report for major cities in China for the fourth quarter of 2018," Beijing, 2018.

[32] Eurostat, "Labour costs in the EU," 2018.

[33] Ministry of Human Resources and Social Security of China, "2017 Statistical Bulletin on the Development of Human Resources and Social Security," Beijing, 2017.

[34] China Meteorological Administration, Assessment method for solar energy resources QX/T89-2008, 1st ed. Beijing: China Meteorological Press, 2008.

[35] J. Dragsted and S. Furbo, "Solar radiation and thermal performance of solar collectors for Denmark," Technical University of Denmark, 2012.

[36] Y. Louvet et al., "Guideline for levelized cost of heat ( $\mathrm{LCoH})$ calculations for solar thermal applications," 2017.

[37] Z. Tian, B. Perers, S. Furbo, and J. Fan, "Thermo-economic optimization of a hybrid solar district heating plant with flat plate collectors and parabolic trough collectors in series," Energy Convers. Manag., vol. 165, pp. 92-101, 2018.

[38] L. Deschaintre, "Development of a Solar District Heating Online Calculation Tool," Energy Procedia, vol. 48, pp. 1065-1075, 2014.

[39] L. Zhang, "Technical-Environmental-Economical Evaluation of the Implementation of a Highly Efficient District Heating System in China," Technical University of Denmark, 2016.

[40] Beijing Municipal Rural Work Committee, "Investigation report on the status quo of clean energy heating application in rural residential buildings in Beijing,” Beijing, 2017.

[41] B. Karlsson and C. Brunström, "Flat Plate or Vacuum Tube Collectors for Swedish Solar District Heating," in Proceedings of The Biennial Congress of The International Solar Energy Society Hamburg, 1987, pp. 1242-1246.

[42] G. Hultmark, A. B. Andersson, and P. O. Box, "The Superiority Of Flat Plate Collectors In Solar District Heating," pp. 1003-1007.

[43] J. Huang, J. Chen, and Y. Xu, "Development trend of flat plate solar collector technology," Constr. Sci. Technol., no. 4, pp. 40-47, 2017.

[44] W. Xu and Z. Liu, "Development and Prospect of Ground Source Heat Pump Technology in China," Build. Sci., no. 10, pp. 26-33, 2013.

[45] B. V. Mathiesen and K. Hansen, "The role of Solar thermal in Future Energy Systems:Country cases for Germany,Italy, Austria and Denmark," Paris, 2017.

[46] K. Hansen and B. V. Mathiesen, "Comprehensive assessment of the role and potential for solar thermal in future energy systems," Sol. Energy, vol. 169, no. March, pp. 144-152, 2018.

[47] National Bureau of Statistics of China, "Heating industry statistical data," 2015. [Online]. Available: http://data.stats.gov.cn/easyquery.htm?cn=C01\&zb=A0B05\&sj=2015. [Accessed: 15-May-2018].

[48] Building Energy Efficiency Research Center of Tsinghua University, Research Report on The Annual Development of Building Energy Efficiency in China 2015. Beijing: China Building Industry Press, 2015.

[49] J. Huang and Y. Xu, "Case Studies on European Solar District Heating Projects," Constr. Sci. Technol., no. 2, pp. 70-78, 2017. 
[50] T. Pauschinger, "Solar thermal energy for district heating," in Advanced District Heating and Cooling (DHC) Systems, Elsevier Ltd., 2016, pp. 99-120.

[51] W. Zhang, "Study on the Rural House Heat Consumption in Cold Areas," Tianjin University, 2011.

[52] Y. Li, "Study on heating Pattern of Rural Residences in Northwest China," Xi'an University Of Architecture And Technology, 2014. 